Wojciech Starościak

University School of Physical

Education in Wroclaw

Halina Guła-Kubiszewska

University of Zielona Góra

University School of Physical Education in Wroclaw

\title{
Designing professional career by students - physical education teachers
}

\section{KEYWORDS}

career, individualism vs. collectivism, career dimensions, factors conducive to professional success

\begin{abstract}
Starościak Wojciech, Dębska Urszula, Guła-Kubiszewska Halina, Designing professional career by students - physical education teachers. „Kultura - Społeczeństwo - Edukacja" nr 2(14) 2018, Poznań 2018, pp. 183-203, Adam Mickiewicz University Press. ISSN 2300-0422. DOI 10.14746/kse.2018.14.14.
\end{abstract}

The study identified physical education students' opinions about and vision of personal career. It was conducted with a questionnaire designed by A. Cybal-Michalska for planning career prospects and career development in modern society by academic youth. Results demonstrate the professional expectations of the sample to be largely met. Students of the University School of Physical Education in Wroclaw are oriented towards individualistic and collectivistic values to a similar extent. Both groups are moderately satisfied with study choices and have a realistic outlook on the difficulties in finding a job consistent with their education. They assess the prospect of a satisfactory career on an equally moderate level, although individualist-oriented students perceive significantly fewer ways of achieving professional success. Collectivistic students emphasize values characteristic of a safe future and working with people and for people. Individualistic students are geared towards innovative and creative activities. Students perceive their careers in the psychological dimension, and select lifestyle and professionalism as the lead guides in career development. 


\section{Introduction}

The notion of career can be defined through the criterion of promotion, that is, promoting someone to a higher job and achieving high position in a given professional environment, as well as through the criterion of employment practice, that is, occupational history in the course of someone's life (Sobol, 2000). According to the psycho-sociological career theory of D.E. Super and his model of the Archway of Career Determinants, career planning and career development are processes that combine the psychology of human development with the social role theory, at the same time emphasizing the role of context (Cosette, Allison, 2007). According to Super's model, the bases of the archway are the biographical and geographical conditions of a subject's life. Two pillars of the archway are, respectively, personal determinants (needs, intelligence, values, aptitudes, interests, social aptitudes, personality, achievements) and social determinants (society, family, school, community, peer groups, the economy, social policy, labor market, employment practices). The arch connecting these two pillars illustrates the interplay between these determinants. Young people perform better at the transition stage from education to the labor market if they gain awareness - best already while at university of the decisions that will have to make in the future together with knowledge of how these decisions relate to other planning (Cybal-Michalska, 2013). University students who work at developing their career prospects are more effective in job search and adapt to the labor market quicker and with more ease.

In the modern reality, we are required to be professionally active and adapt to the constantly shifting context, to build our careers individually, and to think about careers in a new way. These requirements mean also that we need to learn how to be sensitive towards changes in ourselves as well as in the society, how to recognize opportunities and create them, how to take initiative and action (Cybal-Michalska, 2016). The labor market opens up new employment opportunities for young people, often available to them when they are still studying, which is why keeping a position in the labor market is significantly more difficult. Despite having a university degree, many graduates find it difficult to get a job that matches their training. Young people leave planning, decision-making and take action regarding their career in specific moments in life, so-called "breakthrough points", directly related to the coming of age and transitioning between various stages of life in a particular community (e.g., finishing high school, graduating from university, looking for a job). These breakthrough points are also linked to stages of development (e.g., life events, developmental crises, critical life decisions). Irrespective of the development stage and social structures, other factors that can influence the decisions 
concerning one's career include a lack of sense of being or boredom with current life (Krause, 2012). The factors that determine whether students are active in making decisions regarding their career path are, to varying degrees, conditioned by family issues and social status quo, including gender differences. Individual ambitions or expectations from potential employers are also significant. The three-stage pattern of education and employment (secondary school - specialized education, tertiary education - precise field of studies, anticipating occupation consistent with education) is characterized by long-term career predictability, perceived in terms of continuity and permanence. Individual career aspirations - the acquisition of knowledge and experience in a given field - are forward-looking. Career planning, on the other hand, is a systematic process in which an individual selects career goals and sets the path to achieve them (Ruchi, Rachna, Snigdha, 2016).

Career development is the subject of research in psychology, sociology, anthropology, economics, political science, history and geography (Cybal-Michalska, 2013). This interdisciplinary approach to career processes involves identifying its various mental and environmental determinants. Mutual relationships between individuals and groups highly influence what each university student is thinking about his or her career and the impact of environment in is development. This correlation is reflected in the normative orientation: individualism-collectivism (Obuchowski, 1990; Cybal-Michalska, 2013). Individualism and collectivism imply a relatively coherent picture of cognitive, motivational and moral orientation, comprising values and beliefs about the social world and one's own identity, as well as the assessment of the social system and tendencies to express behavior towards social objects (Urban, 2008). Individualism can be understood as a psychological attitude that signifies a tendency to focus on competencies (Daab, 1993) related to knowledge, skills or abilities. While people leaning towards individualism demonstrate such competencies through competition, this is not a quality that prevents them from engaging in cooperation (Grabowski, 2015). At the same time collectivism as a psychological attitude is expressed primarily by the tendency to emphasize the sense of community, cooperation and pursuit of a common goal. Both tendencies can be considered either as two poles of one dimension, or two independent dimensions.

In young people, both the individualistic and the collectivistic tendency is shaped throughout socialization and generalization of social experience. Each tendency is the carrier of a relatively constant set of meanings for individual initiatives or social groups. They differentiate the set of general principles and values followed by an individual in the processing of social life data. At the same time they shape the system of norms and values required for the functioning of an individual in the 
relationship between the individual and the group, as well as, in career-building, in the relationship between the individual and the organization (Dorna, 2001). With regard to professional career, the collectivist model - structurally related to the Self and oriented towards cooperation with others - favors good relationships with co-workers, internal cohesion of the working environment and occupational ties. Features such as community focus, group solidarity and subordination to social norms dominate in this model. An individualistic tendency means that the individual functions as an autonomous entity (i.e., an independent Self) and the collective is rather a subject of the individual's actions. People with individualistic tendencies undertake various tasks for personal fulfillment and to develop their own potential - the society is simply means to achieve that goal. Individualistic or collectivistic people may have different patterns of planning and pursuing their own professional careers.

Due to the intense transformations affecting the current socio-economic space, career- planning is becoming increasingly difficult. Finding a first job after graduation and developing one's own career path are both challenging tasks. To rise to the challenge, already during university education, students should develop not only professional skills but also strategic skills in planning and pursuing their own career path, adjusted both to the relevant organizational culture and styles of networking, as well as in building social capital along with managers and mentors (Bear, 2016). Career Development Training that has been introduced to universities in the West (synergic with career development programs and career development offices) helps students identify early career challenges (create and evaluate career goals, paths and strategies): how to find a mentor, build effective relationships with managers, and achieve work-life balance to succeed in the first job already. When developing these skills, one should take into account that the nature of professional career is changing and that "employment for life" at a single workplace is being increasingly replaced by a "career without borders" attitude (i.e., having many different employers in one lifetime). Acquiring individual career management skills can help in future job mobility and increase the probability of professional success for modern university students.

The goal of this study was to identify the psychological orientation with regard to individualistic and collectivistic values in the studied group of physical education students in the context of their career development. Higher valuation of one of these types of psychological orientation can translate into a preference for such a form of functioning.

Research questions:

1. How do students finishing MA studies in physical education assess the relevance of their study choice and their prospects to have a successful career 
in the field, with respect to the orientation towards individualistic vs collectivistic values?

2. What do the study participants understand under the concept of "career" and how to they understand selected factors of career building in differentiation to the orientation towards individualistic and collectivistic values?

\section{Method}

The study was conducted in 2016 among students of the Academy of Physical Education in Wroclaw finishing their MA studies at the Department of Physical Education, Faculty of Physical Education (PE). The research method employed in the study was a diagnostic survey. We used the questionnaire designed by Cybal-Michalska in 2013 to gather information about the characteristics, views, opinions and facts regarding careers, together with the students' ability to analyze and interpret the above in terms of career planning and career development. The study participants were asked 12 questions regarding the selected categories of career-related phenomena: individualist and collectivist orientation, views and opinions on the quality of contemporary workplace dynamics and their implications for career development, associations with the conceptual category of "career", various career dimensions, individual career image, career success factors, focus on values. The survey was supplemented with socio-demographic part (i.e., independent variables characterizing the studied group): gender, age, place of residence, marital status, material conditions and grade obtained in undergraduate studies (Bachelor degree). For the time of study, the students were granted full anonymity and assured that the collected data would be used exclusively for research purposes. Statistical methods used: tables of amount, average, median, standard deviation, the Mann-Whitney $U$ test of statistical significance, the T-test for dependent samples for individual groups with differentiated rating systems on the Individualism-Collectivism scale

\section{Results}

\section{Socio-demographic characteristics of the study group}

The 132 participants of the survey were students of the second year of Master's degree in Physical Education. The study was conducted in June 2016 during the summer term. Since not all questionnaires were filled in completely, results obtained from 82 students were qualified for analysis. 
Table 1. Socio-demographic data of the studied group of students of PE [N=82]

\begin{tabular}{|c|c|c|}
\hline \multicolumn{2}{|c|}{ category } & \multirow{2}{*}{$\begin{array}{l}\mathrm{N} \\
47\end{array}$} \\
\hline Sex & $\mathrm{F}$ & \\
\hline & $\mathrm{M}$ & 35 \\
\hline \multirow[t]{2}{*}{ Marital status } & $\mathrm{F}$ & 79 \\
\hline & M & 3 \\
\hline \multirow[t]{4}{*}{ Age } & $20-21$ & 1 \\
\hline & $22-23$ & 21 \\
\hline & $24-25$ & 50 \\
\hline & $26-27$ & 10 \\
\hline \multirow[t]{4}{*}{ Place of residence } & $\mathrm{V}$ & 22 \\
\hline & ST & 13 \\
\hline & $\mathrm{T}$ & 18 \\
\hline & LT & 29 \\
\hline \multirow[t]{4}{*}{ Material conditions } & $\operatorname{vg}$ & 9 \\
\hline & $\mathrm{g}$ & 51 \\
\hline & $\mathrm{m}$ & 22 \\
\hline & $\mathrm{b}$ & 1 \\
\hline \multirow[t]{6}{*}{ Bachelor's degree grading } & scl & 0 \\
\hline & $\operatorname{vg}$ & 6 \\
\hline & $g+$ & 25 \\
\hline & g & 31 \\
\hline & s+ & 20 \\
\hline & $\mathrm{s}$ & 0 \\
\hline
\end{tabular}

Source: own work

F - free, M - Married, V - village, ST - Small town, population less than 20,000, T - Town, population 21,000100,000, LT - Large town, population over 100,000, scl - summa cum laude, vg - very good, g - good, s - satisfactory

Among the studied group of students (Table 1) the most numerous group are young people aged 24-25 (60\%) and 22-23 (25\%). The participants live in large towns $(35 \%)$ and in villages (26\%). Most assess their material conditions as good $(62 \%)$ and most of them are unmarried (97\%). The grades obtained on undergraduate level, i.e., Bachelor's degree in Physical Education, vary among the study participants. Good (37\%) and good plus (30\%) make the majority of grades. A lower number of participants obtained a satisfactory plus grade (24\%) and the least numerous group are students with a very good grade $(7 \%)$. 
In summary, the students are adults living both in large towns and in the countryside, assess their material conditions as good, have no family responsibilities, and are well prepared to work as physical education teachers in primary education, which is the credentials they received in undergraduate education.

We used the J.F. Crandall Social Interest Scale to evaluate the individualistic and collectivistic inclination in the studied group of students (Cybal-Michalska, 2013: 250). The scale comprises a set of 10 pairs of traits, one of which serves as a buffer (elegant - tactful). Study participants were asked to select one trait in each of the 10 pairs (all including only positive traits) that they found more valuable and that would make them perceive a person with the selected trait as more valuable.

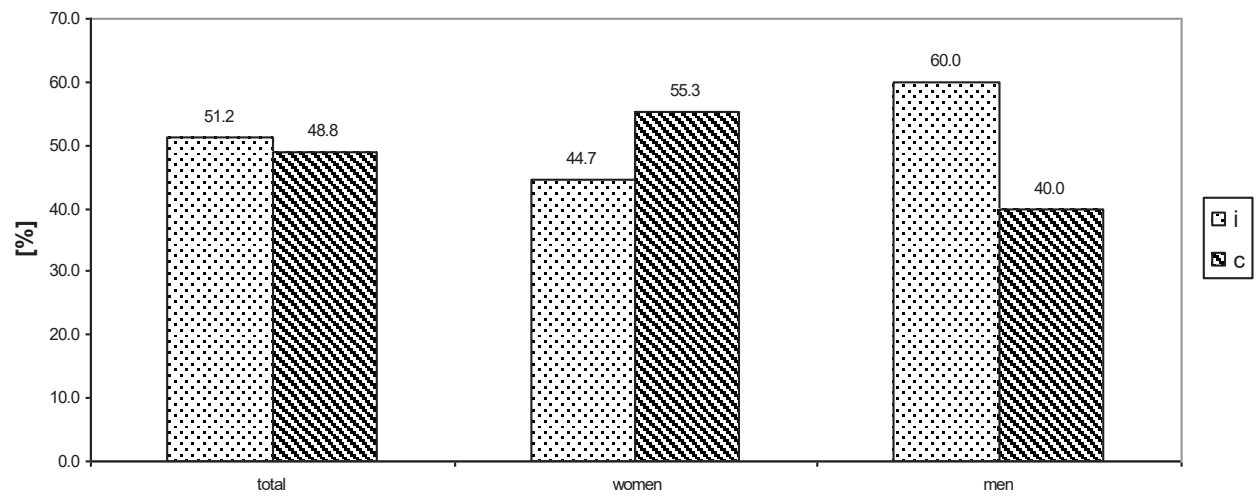

Figure 1. Orientation on individualistic and collectivistic values according to gender in the studied group of students

Source: own work

$\mathrm{i}$ - orientation towards individualistic values, $\mathrm{c}$ - orientation towards collectivistic values

Among the studied group (Figure 1), the individualistic attitude (51.2\% of respondents) slightly dominates over the collectivistic attitude (48.8\%). Gender differences are not statistically significant. Correlation analyses did not reveal any relationship between the results on the individualism-collectivism scale and the age of the respondents, their place of residence, material conditions or professional competences (assessed by the grade obtained in Bachelor's degree). It can be assumed that the studied students are model products of the modern society: they prefer the Westernized, individualistic culture and the consumerist ways of the modern world. This tendency is consistent with the emerging trend observed in developing societies historically conditioned towards collectivism (i.e., promoting community values and solidarity) which is now transforming into individualism. Research shows that individualistic tendencies are more common among men than women. Taking into 
account the various fields of education, the most individualistic approach is exhibited by students of technical, legal, medical and humanist sciences, contrary to, e.g., social sciences (pedagogy) (Cybal-Michalska, 2013). As candidates for the teaching profession (in which pro-social orientation, interaction building and empathy are important), students of physical education should rather affirm the collectivist traits observed in pedagogues (Cybal-Michalska, 2013).

In the presentation of results obtained using the individualism-collectivism scale the traits associated with individualist orientation are marked in all caps. Table 2 below demonstrates a minor advantage of individualistic traits (i.e., orientation towards and finding value in self-fulfillment and development of one's own potential) over collectivistic traits (i.e., finding value in solidarity, responsibility and compliance with social norms).

Table 2. Orientation towards individualistic and collectivistic values on the Individualism Collectivism scale in studied students

\begin{tabular}{|l|c|l|c|}
\hline \multicolumn{1}{|c|}{ Pairs of traits } & [\%] of answ. & \multicolumn{1}{c|}{ Pairs of traits } & [\%] of answ. \\
\hline attentive & $\mathbf{5 3 . 7}$ & INTELLIGENT & 46.3 \\
\hline SENSIBLE & $\mathbf{7 4 . 4}$ & caring & 25.6 \\
\hline ORIGINAL & $\mathbf{6 4 . 6}$ & amiable & 35.4 \\
\hline helpful & 41.5 & AMBITIOUS & $\mathbf{5 8 . 5}$ \\
\hline elegant & 9.8 & considerate & 90.2 \\
\hline generous & 48.8 & TALENTED & $\mathbf{5 1 . 2}$ \\
\hline INTELLIGENT & 32.9 & helpful & $\mathbf{6 7 . 1}$ \\
\hline understanding & $\mathbf{5 6 . 1}$ & ORIGINAL & 43.9 \\
\hline CAPABLE & 50.0 & tolerant & 50.0 \\
\hline caring & $\mathbf{6 3 . 4}$ & AMBITIOUS & 36.6 \\
\hline
\end{tabular}

Source: own work

In the studied group more students exhibited orientation towards the individualistic values over the collectivist values (Table 2). This prevalence is confirmed by the results of doubled traits, such as: intelligent (46.3 and 32.9), original (64.6 and 43.9), ambitious (58.5 and 36.6), helpful (41.5 and 67.1), caring (26.6 and 63.4). We assume that other criteria influenced the selection of particular traits (Cybal-Michalska, 2013). The transitive nature of choices (several traits dominate in more than one pair of traits) can be explained by the existing variations of collectivist tendencies (individuation collectivism ${ }^{1}$ or synthetic collectivism ${ }^{2}$ ) or by

\footnotetext{
1 The individual is a subject but does not lose his/her sense of identity.

2 The individual is aware of his/her distinctiveness, coordinates own interests with the interests of the collective, hence becomes a subject.
} 
the universality of the following traits: capable, sensible and ingenious, which may include collectivist aspects.

Table 3. Significance attributed to personality traits by students oriented towards INDIVIDUALISM and collectivism

\begin{tabular}{|l|l|l|l|l|}
\hline SENSIBLE & $\begin{array}{l}\text { helpful } \\
\text { ORIGINAL } \\
\text { caring }\end{array}$ & $\begin{array}{l}\text { AMBITIOUS } \\
\text { understanding } \\
\text { attentive } \\
\text { TALENTED } \\
\text { CAPABLE } \\
\text { tolerant }\end{array}$ & $\begin{array}{l}\text { INTELLIGENT } \\
\text { generous }\end{array}$ & AMIABLE \\
& & & \\
\hline
\end{tabular}

Source: own work

A lack of significant discrepancies between the orientation towards individualistic and collectivistic values in the studied group of academic youth is a consequence of the significance attributed to each trait (Table 3). In the studied group, the most significant traits were those attributed to the orientation of individualistic values, such as: being "sensible", "original", "ambitious", "talented" and "capable". At the same time, the students equally often chose traits associated with the collectivistic orientation, such as: "helpful", "caring", "understanding", "attentive" and "capable".

The opinions of the studied academic youth (future physical education teachers) regarding the relevance of the choice of the field of study and the prospects of developing a career matching the education depending on the level of professional preparation at undergraduate level of education

The students differ in their opinions $(\mathrm{p}=0.01)$ Mann-Whitney $U$ test in a statistically significant manner (Figure 2). Young people oriented towards collectivist values are much more satisfied with their choice of the field of study, as it is consistent with their interest in the future work they can undertake after obtaining a Master's degree in physical education. The benefits expected from a career in teaching by the students oriented on individualistic values are: working with people of all ages, the ability to develop passions and interests, gaining professional satisfaction. Students focused on the collectivistic values also marked working with people and developing personal interests as preferred occupational benefits, but they also expect psychological and physical comfort and the ability for self-development. 


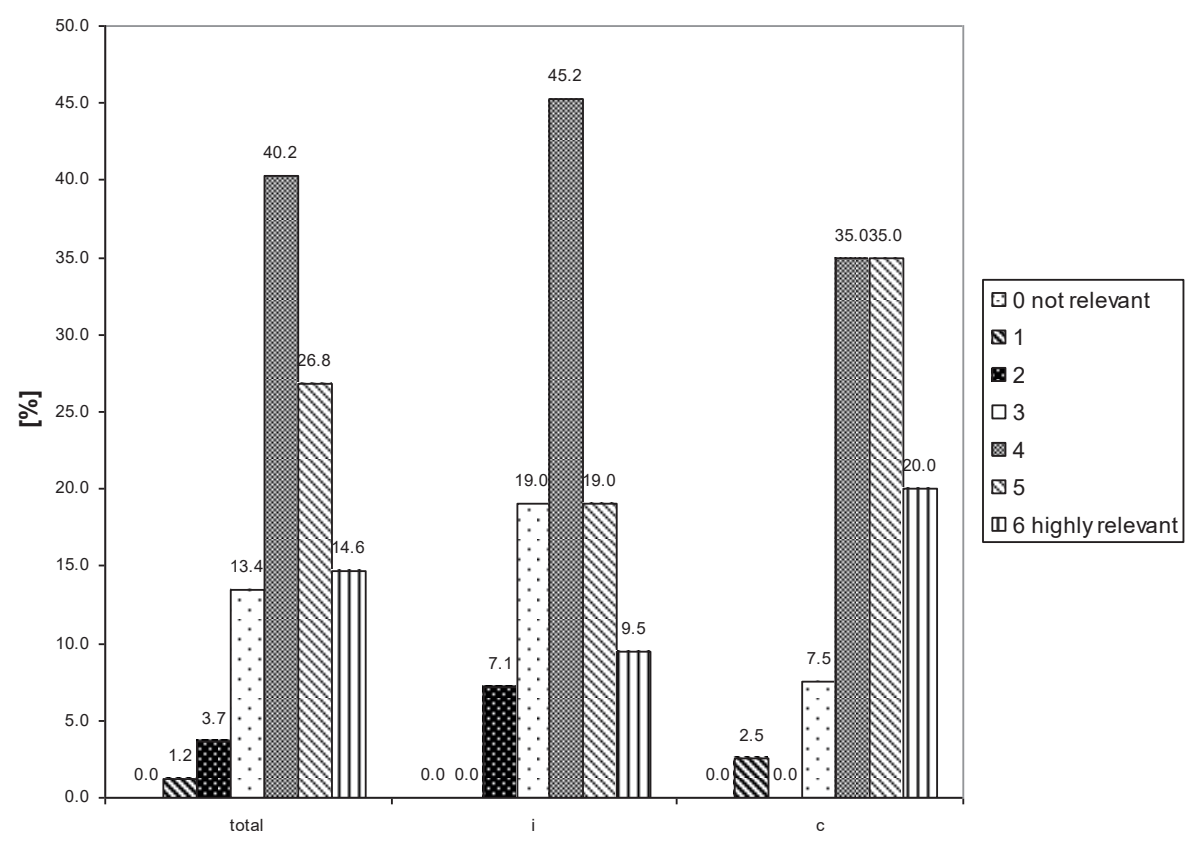

Figure 2. Relevance of the chosen field of study with professional interests of students in differentiation on individualistic and collectivistic values

Source: own work

Responses on a scale from 0 to 6, where 0 means "not relevant" and 6 means "highly relevant"

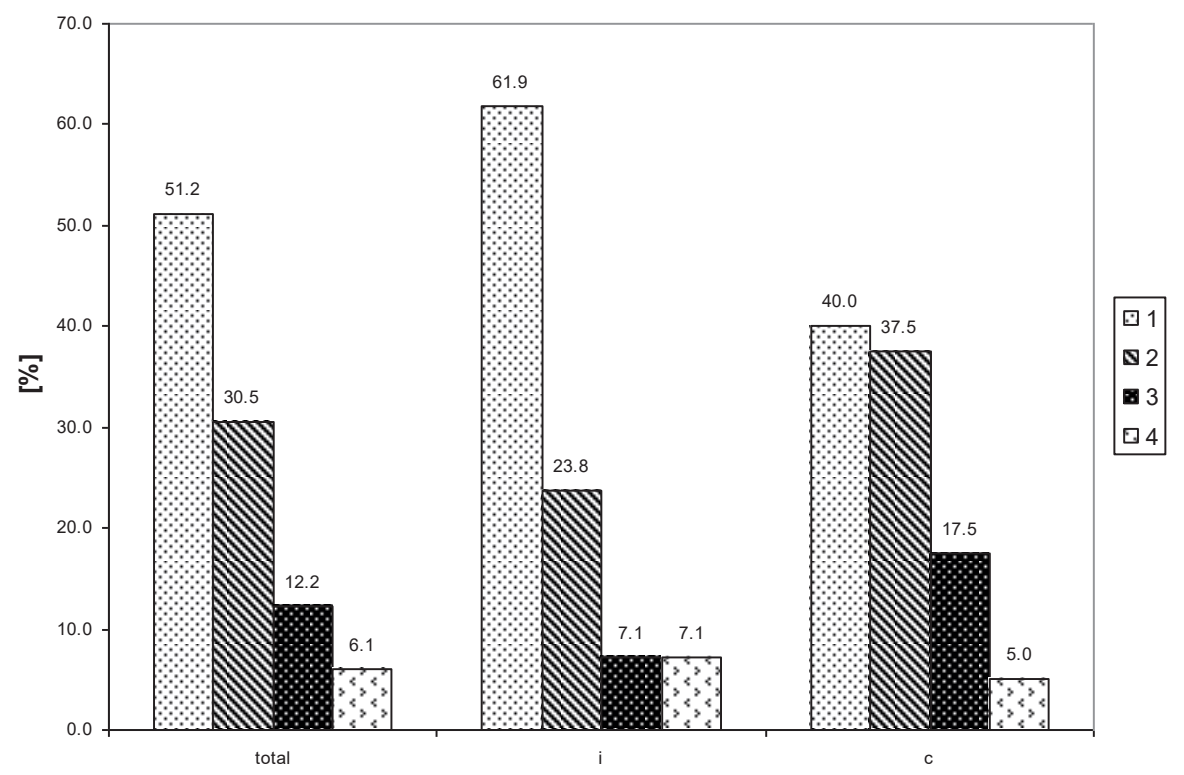

Figure 3. Number of potential employers indicated by students as opportunities to find a job and develop their professional career in differentiation on orientation towards individualistic values vs. collectivistic values Source: own work

1 - one place of work , 2 - two places of work, 3 - three places of work, 4 - four places of work 
Students with individualistic orientation (Figure 3) more often plan to work and develop their career in one workplace. Two or three jobs are more often expected by students who are oriented towards collectivist values. These differences, however, are not statistically significant $(\mathrm{p}=0.101)$, Mann-Whitney $U$ test.

Students who are oriented on either individualistic or collectivistic values assess the relevance of choosing to become physical education teacher in a similar way - as partly relevant. A higher percentage of non-respondents is characterized by collectivist tendencies, but the differences are not statistically significant $(p=0.16)$, Mann-Whitney $U$ test.

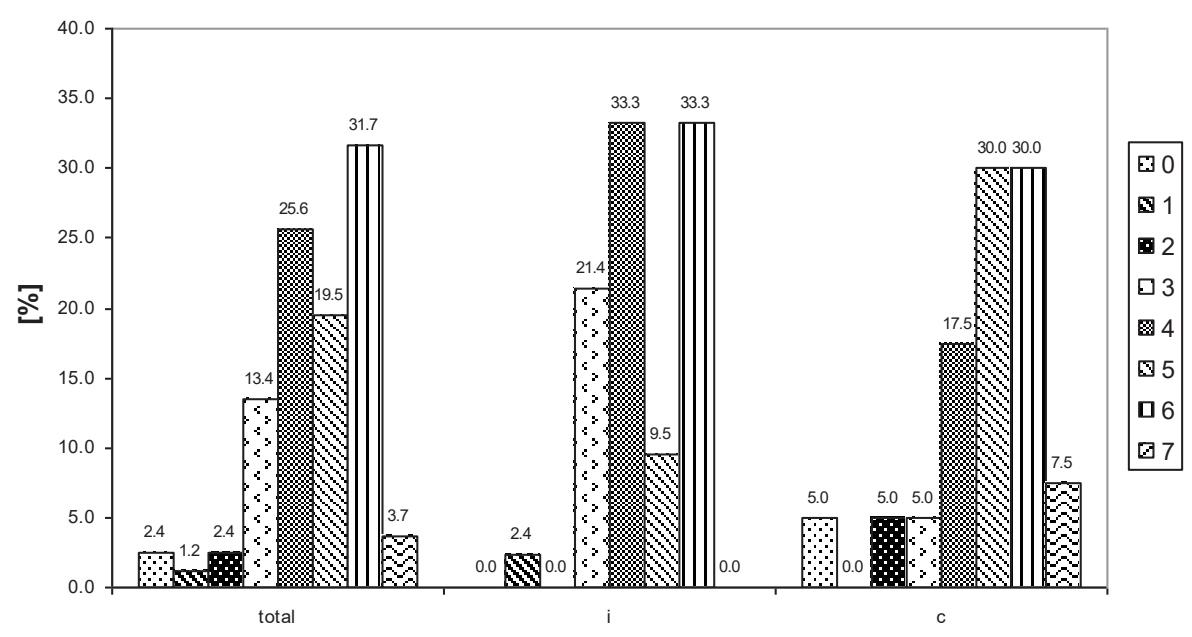

Figure 4. Students' opinions on the relevance of the choice of profession in differentiation to individualistic and collectivistic approach

Source: own work

Responses on a scale from 0 to 6 , where 0 means "not relevant" and 6 "highly relevant"; 7 means "I do not know yet".

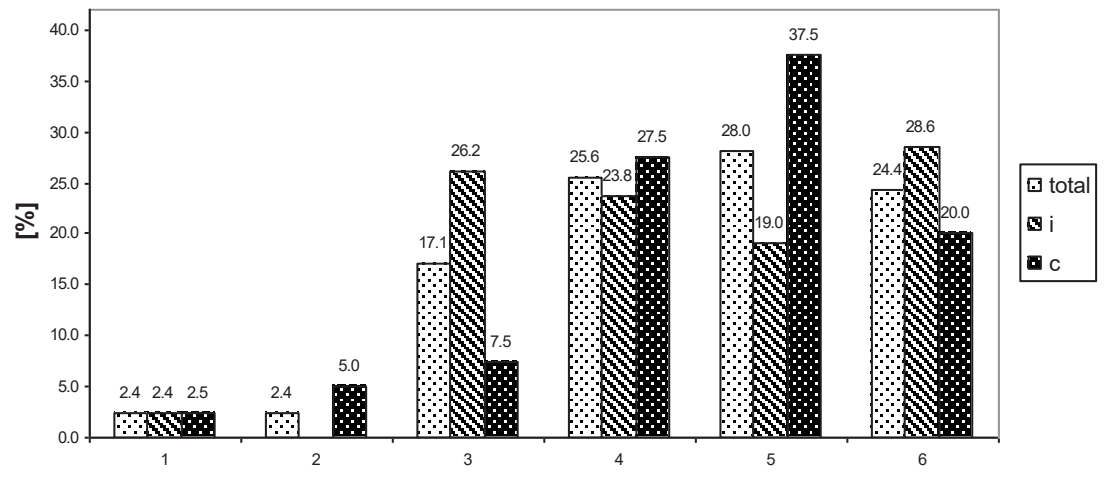

Figure 5. Students' opinions on the chances of success in professional careers in differentiation to individualistic and collectivistic approach

Source: own work

Responses on a scale from 0 to 6 , where 0 means "little" and 6 means "high" 
The students' opinions on the chances of success in professional careers are not differentiated in particular groups (Figure 5). Regardless of orientation towards individualist or collectivist values, students evaluate their chances of success as "very high and high". Students with individualistic orientation are more confident, yet the differences are not statistically significant $(\mathrm{p}=0.662)$ Mann-Whitney $U$ test.

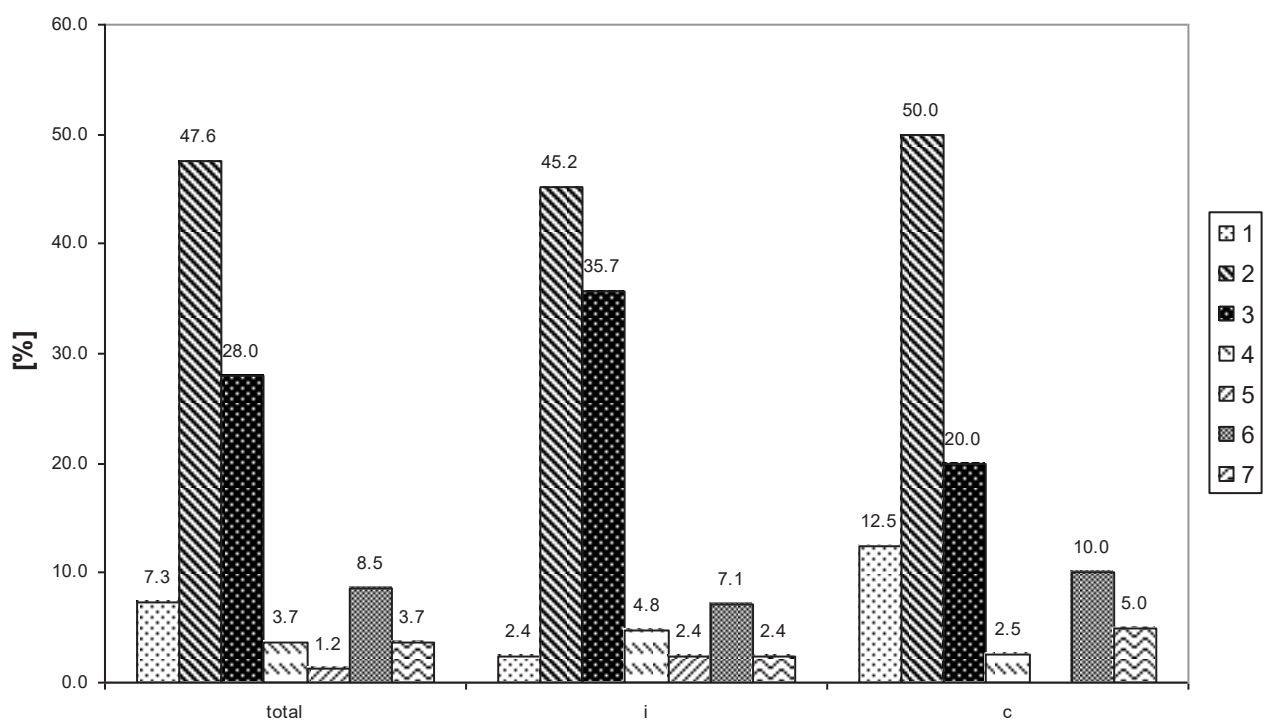

Figure 6. Primary problems after graduation as expected by students in differentiation on orientation towards individualistic values vs. collectivistic values

Source: own work

1 - difficulties in finding any job, 2 - difficulties in finding job relevant to education, 3 - difficulties in finding a job most suited to personal preference, 4 - I do not know yet, 5 - I have not thought about it, 6 - I expect no difficulties at all, 7 - other

Students in both groups do not differ in the assessment of problems they may encounter after graduation (Figure 6). These are mainly difficulties in finding a job that corresponds to their education or simply a job that answers their expectations. They do not feel anxious about finding a job as such.

Student opinions related to the concept of "career" and the importance of selected factors for constructing individual career paths with regard to professional level achievements (undergraduate grading)

A vital characteristic of a professional career is that it is a process which individuals are subject to throughout their occupational history. Career development 
process is defined throughout the life of an individual through many factors, such as: psychological (career as vocation - V, as a tool of self-fulfillment - SF, as a component of individual life structure - CILS), socio-psychological (career as individual response to external role - IRER), sociological (career as uncovering of social roles - USR, social mobility - SM), anthropological (career as a transition from one status to another - TOSA), economic (career as a response to market forces $\mathrm{RMF}$ ), political (career as a realization of self-interest - RSI), historical (career as a correlation of historical consequences - $\mathrm{HC}$ ), geographical (career as a response to geographical circumstances - GC). The associations the studied academic youth had with the conceptual category of "career" were categorized according to the career dimensions developed by Arthur, Hall, and Lawrence (Cybal-Michalska, 2013: 307).

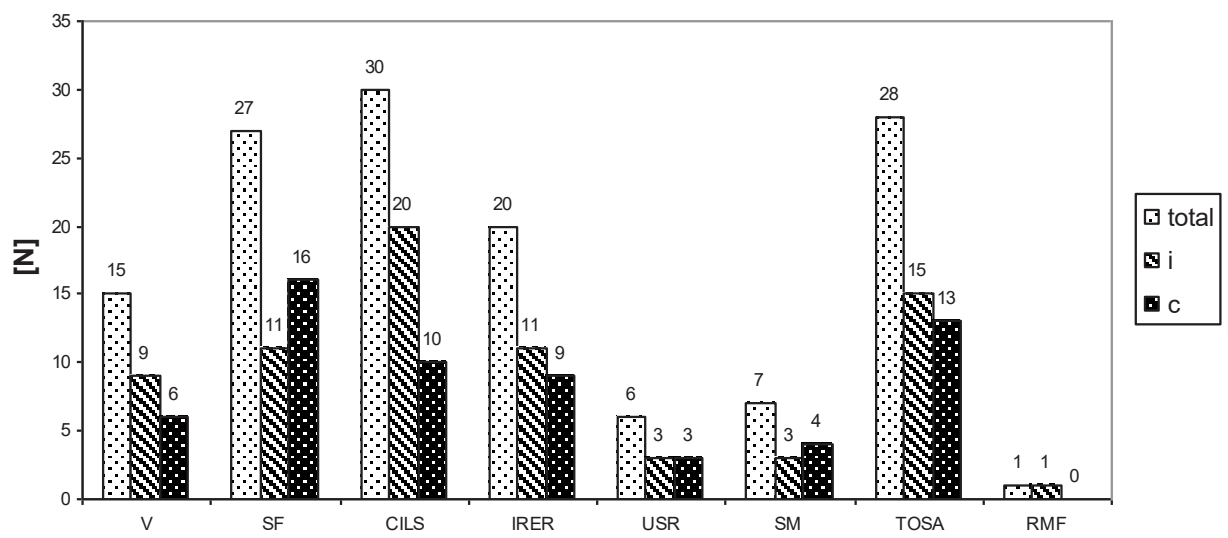

Figure 7. Students' associations with the notion of "career" in differentiation on orientation towards individualistic values vs. collectivistic values

Source: own work

Career dimensions: V - vocation, SF - self-fulfillment, CILS - component of individual life structure, IRER individual response to external role, USR - uncovering of social roles, SM - social mobility, TOSA - transition from one status to another, RMF - response to market forces

Students were granted the opportunity to provide any number of associations. The results are presented in a graph (Figure 7). Observing the distribution of statements from all students we note that they perceive career from several perspectives: psychological - as vocation, a tool of self-fulfillment, component of an individual life structure, as a response to external roles; sociological - as uncovering of social roles, social mobility, transition from one status to another; and from the economic - as a response to market forces. It can therefore be concluded that the psychological dimension of career perception is leading for all respondents of this study. 
Students who value the individualistic qualities higher perceive career as a component of an individual life structure (CILS): with future, finding a job, starting a family, pursuit of dreams and personal development in these areas. Students who value the collectivistic qualities higher, perceive career as a tool of self-fulfillment (SF): opportunity for promotion, satisfaction from work, development of interests and personal opportunities in a given field, professional fulfillment. Regardless of the respondents' individualism-collectivism valuation, the studied group of students see career as a transition from one status to another (TOSA): graduation, internship, specialization, gaining professional qualifications (temporary continuity in the transition of social status).

Career planning depends on many external and internal factors. The respondents assessed the importance of selected factors related to the notion of being in control and the impact of the environment.
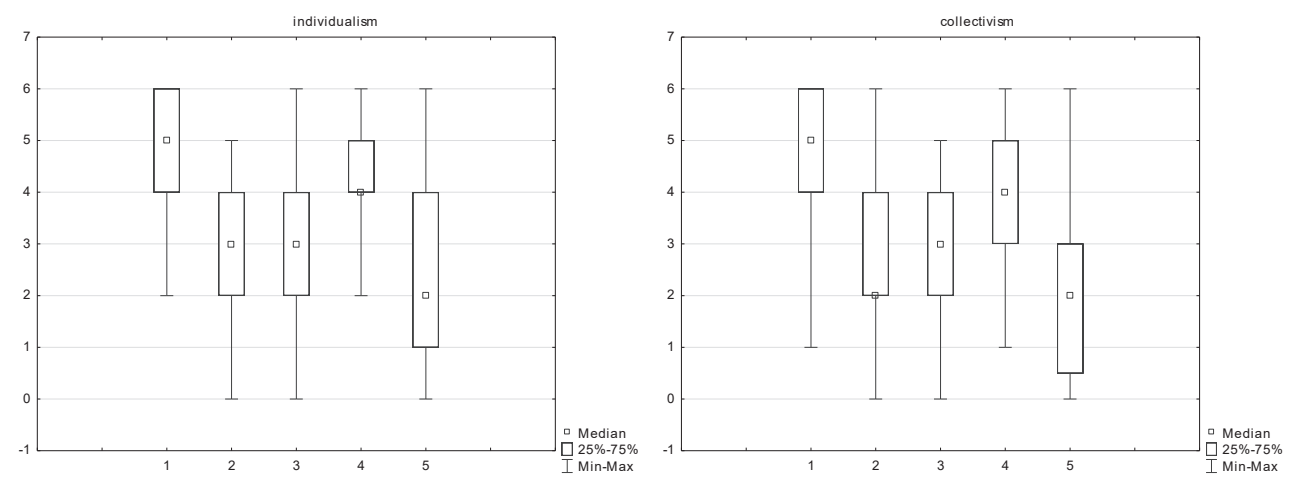

Figure 8. Strength of career determinants in the opinion of study participants in differentiation on orientation towards individualistic values vs. collectivistic values

Source: own work

Strength of determinants, where 0 means "no strength" and 6 means "maximum strength"

1 - what I want and undertake myself, 2 - social pressure, 3 - quality of socio-economic transformations, 4 - properties acquired through education and socialization, 5 - randomness beyond control

In the studied group, career decisions are determined by individual preferences. Students in both groups (Figure 9) are fully convinced that they themselves decide on the course of their careers and see education and socialization as important in career planning. Small importance is attributed to accidental, uncontrolled life events. Students with the collectivist angle feel less internal and social pressure in career development. An important factor for building a career is also the importance of the quality of modern world transformations. 

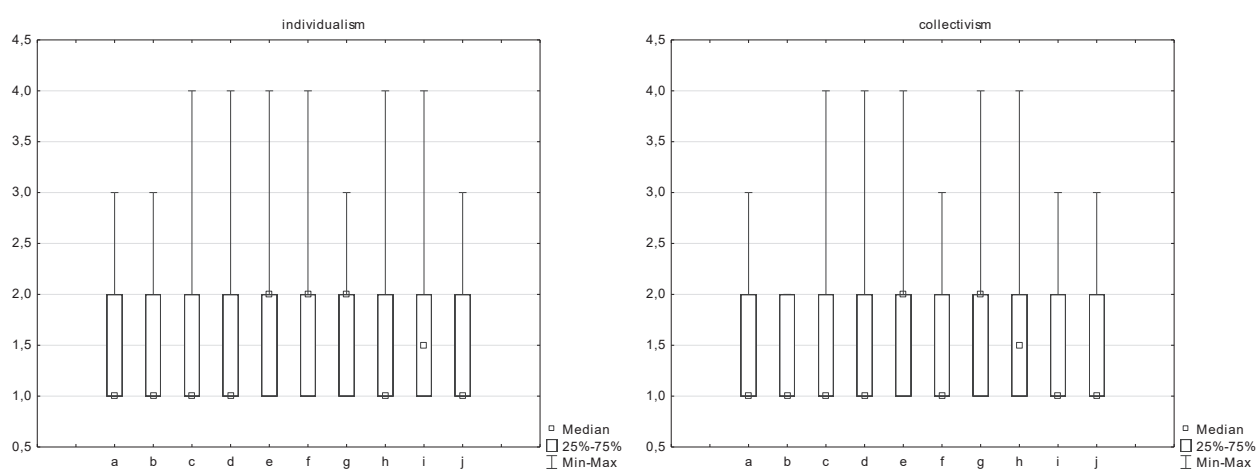

Figure 9. Student opinions on the importance of quality of the transformations of the contemporary world for career development in differentiation on orientation towards individualistic values vs. collectivistic values

Source: own work

Consequences: 1 -serious, 2 - minor, 3 - no consequences, 4 - no occurence, a - changes in the demographic structure of a globalizing society, $\mathbf{b}$ - changes in the world of work, $\mathbf{c}$ - breakdown of global market mechanisms, d - rising unemployment, e - economic inequality: a rising gap between the developed countries and Third World countries, $\mathbf{f}$ - changes in employment structure, $\mathbf{g}$ - intensification of world-wide social relations, understood as a global network of interdependencies and links between states and societies that forms a global system, $\mathbf{h}$ - intensification of political relations across borders, related to restrictions on the autonomy of the nation state as a sovereign and autonomous entity political life, $\mathbf{i}$ - deepening and expanding network of economic connections across national and regional borders and leaving a single global market for goods, services and capital, $\mathbf{j}$ - changes in education that answer general changes in the world of work and the structure of the occupation market

The correlation analyses did not reveal any relationship between results on the individualism-collectivism scale and views on the importance of the quality of modern world transformations and their consequences for career development (Figure 9). In both groups, students perceive all consequences as grave, especially: changes in the demographic structure of a globalizing society, changes in the world of work, the collapse of global market mechanisms, rising unemployment and changes in education answering the changes in the world of work and the structure of the labor market. Uneven economic level of countries (increasing gap between the developed world and Third World countries) and the intensification of world-wide social relationships (understood as a global network of interdependence and links between states and societies that form the global system) are of minor importance.

Other factors that promote career success, called career "anchors" or "guides", have been categorized into eight priority groups (Cybal-Michalska, 2013). Areas where academic youth can increase their chances of career success are: professional competence, motivation, and career-related values that young people find satisfying. The career "guides" are: lifestyle, sense of security and stability, profes- 
sionalism, autonomy and independence, dedication to others, creativity and entrepreneurship, challenge and leadership.

The importance of each factor for success in career planning is presented in a hierarchical chart ${ }^{3}$.

Table 4. Choices of career "guides" fostering professional success in the group of studied students

\begin{tabular}{|l|l|}
\hline \multicolumn{1}{|c|}{ Individualist orientation } & \multicolumn{1}{c|}{ Collectivist orientation } \\
\hline life style / professionalism & life style / professionalism / security and stability \\
\hline $\begin{array}{l}\text { autonomy and independence / security and stabil- } \\
\text { ity / creativity and entrepreneurship }\end{array}$ & $\begin{array}{l}\text { creativity and entrepreneurship / devotion to oth- } \\
\text { ers / challenge/ autonomy and independence / }\end{array}$ \\
\hline challenge / devotion to others & leadership \\
\hline leadership & \multicolumn{2}{|l}{} \\
\hline
\end{tabular}

The central place in the value system of the studied academic youth (Table 4) is occupied by lifestyle (career is one of the many domains of life of an individual oriented towards achieving a sense of satisfactory mental well-being, balance and harmony) and professionalism (professional competence, aiming at being a professional in a selected field is more important than climbing up the career ladder.) The least preferred value in pursuing a career is leadership. This value is often identified with an increase of power and broadening of one's sphere of influence, and is probably too far ahead in the future for the young people who are about to enter the labor market.

Students with an collectivist orientation attach higher value to security and stability (need for a clearly defined future) and dedication to others (fulfilment of humanist values, desire to help others). They highly value "autonomy and independence", i.e., the ability to decide on the quality of work and the sense of freedom in action (no barriers, restrictions). The students mentioned challenge as one of career "anchors" (typical for young people oriented to individualistic values), which means a tendency for risk-taking and competing, seeking novelty and resisting difficulties in work and occupational roles.

Students with an individualist orientation are more creative to develop their own careers, which is reflected in their choice of "creativity and entrepreneurship" as highly valued career "anchors". This demonstrates the students' inclination to recognize and solve problems, to introduce innovative changes in their

\footnotetext{
${ }^{3}$ Further value levels for individual guides were determined on the basis of statistically significant differences in the T-test for dependent samples for individual groups with differentiated rating systems on the Individualism-Collectivism scale $(\mathrm{p}=0.05)$.
} 
lives, as well as to their cognitive curiosity, mobility and entrepreneurship and the belief in the positive outcome of creative activities conducted in the planned future.

\section{Discussion}

Many factors affect the process of exploring, constructing, and making career-related decisions by academic youth. Some of these factors are conducive to these tasks, others inhibit them: external barriers tend to fuel students' indecisiveness. Said factors are being researched from various academic perspectives. The goal of this research was to identify the main impediments in career planning faced by young people and to identify the barriers that may lead to a lack of performance in this regard (Ukil, 2016).

Study participants defined their orientation towards individualistic and collectivist standards, yet did not exhibit particular preference for either.

The principles for educating future Physical Education teachers say that the students should, as future educators, exhibit collectivist tendencies, which would be in line with Cybal-Michalska's results (2013). However, the results of our research have not confirmed such a regularity. An almost equal level of orientation on collectivist and individualist values represented by the students in the study group can be perhaps explained by the general nature of sports. Sport can be practiced by collectivist-oriented people (e.g., team sports where good team is all) and individualist-oriented people alike (sports focused on individual success, breaking records etc.). Both types of sportsmen are essential and are not mutually exclusive in this profession. It is also worth noting that, following psychological typologies, simple, clear-cut classification of personality traits is impossible (Nosal, 1992). Most commonly, the studied subjects found themselves on a scale between extreme traits forming the individualism-collectivism opposition. Referring to the result of the question on the relevance of choice of the field of study, the individualistic-oriented students assess it as slightly lower.

This shows that the lack of collectivistic tendencies makes them uncertain about their career path. These students also exhibited a preference to follow one profession is their lives, which is another factor that will make it more difficult for them to find a job and pursue a professional career in the modern, changing world. Collectivist-minded people, who see more work opportunities for themselves, seem to have better odds in this regard. They are more open and flexible in thinking about their careers, although they do not focus on the planning at a fully satis- 
factory level. Previous studies demonstrate that the skills necessary for effective job search (through advisory offices) and the awareness of career goals and personal decision-making skills (Pothukuchi, Kumar, Dash, 2014) should be developed already at education level. Students should be encouraged to use business tools for personal development to ensure long-term career success (Adams, Allred, 2013). As other studies show, the introduction of career-planning to the education process proves effective already at secondary school level (Gardnem, 2013). Gaining knowledge and experience in a given field determines future-oriented aspirations that guide career planning. This is a systematic process that assists in setting career goals and choosing the right path for their achievement (Gautam, Nigam, Mishra, 2016). During education, e.g., by participating in appropriate courses, workshops, training, through teachers providing them with detailed career information, students should acquire the strategic skills to design their careers. Secondary school students and university students who do that show increased self-esteem and higher expectations regarding the results of such planning, which help them visualize the details of their future careers (Bear, 2016; Powers \& Myers, 2017). Intervention counseling aimed at developing cognitive skills, social competence and personal effectiveness should also be introduced (Pinchart, Juang, Sibereisen, 2004; Gnilk, Novakovic, 2017; Belser, Prescod, Darie, Dagley, Young, 2017).

While the transformation processes of the modern world give young people many opportunities for development, they also show many contradictions, uncertainties, ambiguity, paradoxes and risks (Bąbka, 2012). The shift away from community-driven values and accountability to society (collectivist approach, orientation "towards others") to a more individualistic approach of self-fulfillment (orientation "towards self") is increasingly visible and powerful. The social norms of equality and cooperation are replaced by greater exposition to freedom and competition (Melosik, 2004).

The analyses of results of this study were aimed at recognizing certain subjective conditions (psychological orientation on individualistic or collectivistic values) related to individual behavioral tendencies towards various social objects in students, future physical education teachers, in the context of their perceptions of career. The studied group are members of a generation oriented towards individualism, who at the same time value collectivist concepts similarly to junior high school students and academic youth studied by other authors (Bąbka, 2012; Urban, 2008; Cybal-Michalska, 2013). The studied students value individualistic standards (autonomy and agency, emotional independence), at the same time attaching importance to the harmony of coexistence with other people. The results of the study indicate that there is no reason to infer that physical education stu- 
dents with individualistic or collectivistic orientation differ in any way in how they define the concept of career and assess the factors involved in career planning.

The tendency to think in terms of individualism (independence in deciding to enter into cooperation, good self-esteem, individual attitude to life) may not facilitate cooperation and pro-social behavior or promote cooperation. Physical activity based on competition (carried out by individuals and in teams), which is characteristic for physical education students, cannot be regarded as a typical component of the individualistic orientation. Some individualists combine self-reliance with competition and others not - the difference of attitudes is exemplified in different cultures. That is why individualism and collectivism can be characterized as either vertical or horizontal tendencies, according to how much emphasis is put on equality (Grabowski, 2015). Each person and each culture can be characterized in both dimensions, developed to varying degrees. Perhaps this explains why similar percentages of students participating in the survey declared individualistic and collectivistic orientation, and why these two groups do not differ in their perception of career opportunities, in the understanding of the notion of "career" and in the value attached to selected factors of career-building.

The results of the study demonstrate only statistically significant difference between individualist and collectivist-oriented students was observed: the relevance of the choice of studies for personal interests. Collectivist-oriented students proved more certain as to the relevance of the choice of field of study.

In summary, the participants of the study, both individualistic and collectivistic students:

- to a similar degree assess the personal relevance of choosing the profession of physical education teacher (assessed at 50\% with a higher percentage of non-respondents to this question characterized by collectivist values);

- assess their chances of professional success as "very high and high"; individualists are fully convinced of future success;

- see the possible problems after graduation in difficulties in finding a job that corresponds well with their education profile or personal preference;

- from a psycho-sociological perspective, students who value individualism higher perceive career as a component of individual life structure, while those who value collectivism higher perceive it as a tool of self-fulfillment; to all study participants career is a status transition;

- notice modern world transformations and see serious consequences thereof for their careers in: changes in the demographic structure of a globalizing society, changes in the labor market, the collapse of global market mechanisms, rising unemployment and changes in education; at the same time, 
they attribute less significance to the economic inequality between countries and to the intensification of world-wide social relations;

- for students, the leading guides to career development are lifestyle (mental well-being, balance and harmony) and professionalism (professional competence); the career value least preferred by students is leadership; academic youth with a collectivistic orientation emphasize the importance of a safe future (security and stability) and the ability to work with people and for people (sacrifice for others), whereas students with an individualistic approach value creativity and entrepreneurship, which means an inclination for creative work in the future.

\section{Conclusions}

Students of the University School of Physical Education in Wrocław are oriented towards individualistic and collectivistic values to a similar extent. Both groups are moderately satisfied with their choice of study. They are also moderate in assessing the possibilities of career development, although individualist-oriented students perceive significantly fewer ways of achieving professional success, while collectivist-oriented students see slightly more of them. While students perceive the main "guides" in planning their career paths similarly, they differ in the choice of other significant values, such as the sense of occupational stability and working for other people (collectivist approach) and creativity in innovative solutions (individualist approach).

The results obtained in this study corroborate previous research, demonstrating that individualism and collectivism can coexist, and the domination of one orientation over the other is an outcome of a particular situation. Today, individualism and collectivism are not treated as opposing poles but as independent dimensions, perceived as potential ways of reacting to certain situations and not as fixed personality types (see Reykowski, 1992).

\section{References}

Adams L., Allred A.T. (2013). The First Step in Proactively Managing Students' Careers: Teaching Self-SWOT Analysis. "Academy of Educational Leadership Journal” 17(4), pp. 43-51.

Bąbka J. (2012). Orientacja na wartości indywidualistyczne vs. Kolektywistyczne jako podstawa wyjaśniania zachowań kooperacyjnych. „Teraźniejszość - Człowiek - Edukacja” 2958, pp. 121-138. 
Bear B. (2016). A Strategy for Improving Behaviors of Preschoolers Identified as at Risk or Developmental Delayed. "TEACHING Exceptional Children" 41(5), 54-59.

Belser C.T., Prescod D., Darie A., Dagley M., Young, C. (2017). Prediciting undergrauduate student retention in STEM majors based on career development factors. "Career Development Quaterly" 65(1), pp. 88-93.

Cossette, I.J., Allison Ch.J. Donald E. (2007). Super's life-space, life-span theory of career development. [In:] Ch.J. Allison, I. Cossette (eds). Proven Practices for Recruiting Women to STEM Careers in ATE Programs. Lynnwood.

Cybal-Michalska A. (2013). Młodzież akademicka a kariera zawodowa. Kraków.

Cybal-Michalska A. (2016). Proactive behavioral orientation of a subject as a process of nvesting in career capital in the world of "Boundaryless Careers". "Advances in Physical Ergonomics and Human Factors", pp. 931-942.

Dorna N. (2001). Indywidualizm- kolektywizm jako źródło międzykulturowych różnic w zakresie zachowań komunikacyjnych. [In:] Z. Blok (ed.). Społeczne problemy globalizacji, vol. 19, pp. 161178.

Gautam R., Nigam R., Mishra S. (2016). A study of determinants of career aspirations vis a vis career planning among MBA students. "Global Journal of Enterprise Information System" 8(3), pp. 58-64.

Gardner, L.L. (2013). Teaching teachers about supply chain management to influence students' career and education choices. "Decision Sciences Journal of Innovative Education" 11(2), pp. 185-192.

Gnilka P., Novakovic A. (2017). Gender differences in STEM students' perfectionism, career search self-efficacy and perception of carter barriers. "Journal of Counseling and Development" 95(1), pp. 56-66.

Grabowski D. (2015). Indywidualizm, kolektywizm a etyka pracy. „Polskie Forum Psychologiczne” 20(1), pp. 62-77.

Krause E. (2012). Planowanie rozwoju kariery zawodowej przez studentów: między wyobrażeniami a strategiami. Bydgoszcz.

Nosal Cz. (1992). Diagnoza typów umystu. Warszawa.

Obuchowski K. (1990). Kolektywizm - indywidualizm - ideologizm. [In:] J. Reykowski, K. Skarżyńska, M. Ziółkowski (eds), Orientacje społeczne jako element mentalności. Warszawa.

Pinquart M., Juang L., Sibereisen R. (2004). The role of self-efficacy, academic abilities, and parental education in the change in career decisions of adolescents facing German unification. "Journal of Career Development" 31(2), pp. 125-142.

Pothukuchi B.R., Kumar S.A., Dash M. (2014). A study of the impact of self-regulated learning on academic and career goal clarity among postgraduate women students of Bangalore. "The IUP Journal of Soft Skills" 8(2), pp. 39-48.

Powers S.R., Myers K. (2017). Vocational anticipatory socialization. "College Students' Reports of Encouraging / Discouraging Sources and Messages” 44(5), pp. 409-424. 